\section{ECONOMICS}

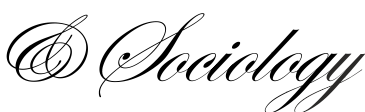

Mustapa, W.N.W., Al Mamun, A., \& Ibrahim, M.D. (2019). Evaluating the effectiveness of development initiatives on enterprise income, growth and assets in Peninsular Malaysia. Economics and Sociology, 12(1), 39-60. doi:10.14254/2071-789X.2019/12-1/2

\title{
EVALUATING THE EFFECTIVENESS OF DEVELOPMENT INITIATIVES ON ENTERPRISE INCOME, GROWTH AND ASSETS IN PENINSULAR MALAYSIA
}

Wan Nurulasiah binti Wan Mustapa, Universiti Malaysia Kelantan, Malaysia

E-mail:

xiaojienurulmustapa@gmail.com

\author{
Abdullah Al Mamun, \\ Universiti Malaysia Kelantan, \\ Malaysia \\ E-mail:abdullah.a@umk.edu.my
}

Mohamed Dahlan Ibrahim, Universiti Malaysia Kelantan, Malaysia

E-mail:dablan@umk.edu.my

Received: September, 2018

1st Revision: November, 2018

Accepted: January, 2019

DOI: $10.14254 / 2071-$

789X.2019/12-1/2

JEL Classification: F61, G21

\begin{abstract}
Malaysian development organizations offer a diversity of initiatives to uplift the socio-economic conditions among low-income micro-entrepreneurs. This study examined the impact of two initiatives namely access to working capital and enterprise development training programs on Kelantanese micro-enterprise income, growth, and net-worth of assets By adopting a crosssectional design, data were collected by means of random selection across the participants' lists of three development organizations. A total of 450 micro-entrepreneurs from seven districts in the state of Kelantan responded. Multiple regression analyses are used to analyzed the data. The regression analysis shows that access to working capital and enterprise development training programs have positive impacts on the income, growth, and net worth of assets owned by Kelantanese micro-enterprises. This study extends the limited literature of micro-enterprise income, growth and asset net worth, and the role of working capital and enterprise development training programs, to provide new understandings on the effectiveness of contemporary development initiatives.
\end{abstract}

Keywords: micro-credit, training, micro-enterprise income, growth, assets, cross-sectional, quantitative analysis

\section{Introduction}

Development initiatives, delivered in the form of micro-credit and enterprise management training programs, are increasingly used as the predominant instrument for poverty alleviation and socio-economic upliftment efforts among low-income microentrepreneurs in developing countries. To serve the low-income micro-entrepreneur cohort, micro-credit is chiefly designed and developed to provide start-up and working capital to boost micro-enterprise performance, whereas enterprise development training programs are aimed at enhancing essential skills in money and business management, including marketing strategies to increase micro-enterprise income, growth, and assets. The expected outcome of 
these two forms of assistance, financial and non-financial, is enhanced the robustness of micro-enterprise income generating activities. Evidently, micro-enterprise is often considered as an antecedent of income generation, which could lead to a decline in poverty rate as part of achieving the broader goals of sustainable socio-economic development.

In Malaysia, micro-enterprise is defined by the National Small and Medium Enterprise (SME) Development Council as companies with a sales turnover of less than RM 300000 or full time employees less than 5 for manufacturing, services and other sectors (Bank Negara Malaysia, 2013). Micro-enterprises constitute $76.7 \%$ or 496,458 of the total 645,136 registered SMEs. In the state of Kelantan, micro-enterprises constitute only $5.1 \%$ of national SMEs established (DOSM, 2016). Nationally, micro-enterprises' contribution in key economic sectors has been significant. The highest contribution is in the services sector at $79.5 \%$ of total SMEs while the second largest contribution is in the manufacturing sector at $57.1 \%$. About more than half of micro-enterprises' contribution is in the agriculture sector by as much as $56.2 \%$ of the total SMEs established. Other smaller contributions are in the construction sector $(43.4 \%)$, the mining and quarrying sector (19.2\%), and small enterprises which account for $42.1 \%$ of the total SMEs established (SME Annual Report, 2015).

To spur further growth amongst micro-enterprises, the Malaysian government established several development organizations tasked to provide access to working capital and enterprise development training programs to low-income microentrepreneurs. The first and largest is Amanah Ikhtiar Malaysia (AIM), followed by the National Entrepreneurs Economic Group Fund (TEKUN), then to serve the fishing community is the Malaysia Fisheries Development Board (LKIM). Established on 17 September 1987, AIM is governed by the Trustees (Incorporation) Act 1952. On the other hand, TEKUN was established in November 1998 as a ministerial agency under the Ministry of Entrepreneurial and Cooperative Development. Another ministerial agency is LKIM. Incorporated under Act 49 of the Malaysia Fisheries Development Board Act 1971, LKIM was established under the Ministry of Agriculture and Agriculture Base Industry and is tasked to provide small-scale working capital to the targeted group. Together, these three development organizations provide a diverse portfolio of micro-credit and training

AIM training were designed to help micro-entrepreneurs build and cultivate understanding and skills in monitoring the risk management plan. Whereas the TEKUN's Seminar of Entrepreneurship Fundamentals trains new borrowers on basic marketing and accounting. LKIM only offered one section for loan namely funding section. Meanwhile, LKIM's targeted funding encompasses various business and operational aspects of the fisheries micro-enterprises - from working capital to develop, and from asset acquisition to commercialization. By providing access to working capital and enterprise development training programs as such, AIM, TEKUN and LKIM seek to fulfill the common objective i.e. to increase the robustness of micro-enterprise performance.

Evidently, the effect of micro-credit and training programs have been well recorded as positively significant in post-participation micro-enterprise income and assets(Al-Mamun, Malarvizhi, Hussin \& Tan, 2012; Md Saad, 2011). Conversely, a few studies argued the effectiveness of development initiatives on improving the socio-economic conditions of participants (Islam, 2007; Rahman, Rafiq \& Momen, 2009). Therefore, this study intended to evaluate the effectiveness of development initiatives on micro-enterprise income, growth, and assets in the state of Kelantan, Malaysia. The main purpose of examining Kelantan points to the 2017 poverty figures that represent the state as the poorest in Peninsular Malaysia (EPU, 2018). 


\section{Literature Review}

\section{Theoretical Foundation}

This study is framed by two underpinning theories: modern development theory and human capital theory. Modern development theory provides the important role of access to working capital to address income inequalities among low-income micro-entrepreneurs within the broader goals of poverty eradication. The study by Claessens and Tzioumis (2006) mentioned that the lack of access to working capital could be the factor of the generation and persistence of income inequality and the poverty trap, which follows lower growth. Access to working capital increases the low-income micro-entrepreneurs' abilities to take advantages of income-generating opportunities, which lead to increase the enterprise income and assets (AlMamun, Abdul Wahab \& Malarvizhi, 2010). It is expected that by measuring the impact of micro-credit programs among low-income micro-entrepreneurs and their micro-enterprise income, growth, and assets, the underlying assumptions can be strengthened.

The theory of human capital stipulates that investments in the form of education and job training enhance the individual's level of knowledge, skills, and abilities (Becker, 1993), and when effectively translated as the individual's capital, an increase in future potential enterprise income and assets can be expected. Belas et al., (2015), mentioned that, the performance of an enterprise, it depends on the skill and abilities of an entrepernuers according to entrepreneurs themselves and they also stated that, in order to generate more income, an entrepreneurs must able to take any risks involving their bsuiness. In almost every study measuring micro-credit performance, researchers examined the effectiveness of training programs in improving the abilities of low-income micro-entrepreneurs in taking advantage of opportunities to generate additional income and accumulate more assets (Al-Mamun, Abdul Wahab, Malarvizhi, \& Mariapun, 2011; Omar, Noor \& Dahalan, 2012; Samer et al., 2015; Terano, Mohamed \& Jusri, 2015). Thus, committed to socio-economic development, development organizations (such as AIM, TEKUN, and LKIM) provide training programs to develop abilities to expand income, to educate proper credit utilization, and to improve money management skills, and when combined can increase micro-enterprise income, growth and assets owned by low-income micro-entrepreneur participants.

\section{Impact of Development Initiatives}

The mission of development organizations is to deliver financial and non-financial initiatives that focus on poverty eradication within broader sustainable development goals. The objective of these initiatives is for the targeted group to attain an outcome of increased income and assets, which is sustainable in the long-term, thereafter leading to reduced economic vulnerability and an eventual end to poverty. The joint efforts of multilateral institutions such as the United Nations, the World Bank, and non-governmental organizations (NGOs) with governments can better aid low-income micro-entrepreneurs to increase income and assets.

Malaysia's longstanding efforts in poverty eradication see the government in joint efforts with the private sector and non-government organizations (NGOs) to deliver development initiatives to low-income micro-entrepreneurs through three development organizations namely AIM, TEKUN, and LKIM. Together, these organizations roll-out a diverse portfolio of financial and non-financial assistance, commonly consisting two products: micro-credit and enterprise development training programs as the income generating activities among low-income micro-entrepreneurs (Anderson \& Laura, 2002). However, according to Bilan (2009), there are two types of programs to support poverty 
eradication programs such as government support programs and financial support programs. The government support programs is divided into few categories such as business environemnt, capabilities or access to loan and legal and regulatory environmnt finance however, the activities with financial focus on finance development, direct financial support and loan guarantees.

Micro-credit and enterprise development training programs are initiatives for income generating activities to ensure that 10 percent of the world population lived on less than US\$1.90 a day receive working capital, training programs and other assistance (World Bank, 2018). Uotila's (2005) study supported the earnest participation in micro-credit and training programs as this had not only increased participants' enterprise income and assets, but also the welfare of households over time. Another study also reported similar significant positive results of earnest participation in micro-credit programs on business investment and registration (Dunn, 2005). Bernat et al., (2009), stated that, the majority of the respondents in their study wanted to set up theirs own business in a few years, once they had accumulated some experience, this is because, they believed that the profit will arise in a year or few years after they running a business. Additionally, Swain and Varghese's (2009) study in India revealed micro-credit to be positively related to livestock accumulation, yet had no impact on land value nor business wealth, including physical assets. Conversely, a Pakistani study argued that no significant positive impact was indicated on sales or profits despite two-thirds of the total participants received micro-credit facilities for their micro-enterprises. Therefore, this study intended to measure the impact of access to working capital and enterprise development training programs on micro-enterprise income, growth, and assets among the participants of development initiatives in the state of Kelantan, Malaysia.

\section{Impact on Micro-Enterprise Income}

Micro-credit and training programs are essential poverty alleviation tools to increase micro-enterprise income and growth worldwide. By combining both sets of tools with social capital and human capital, micro-enterprise income, assets, and growth can be increased. In this study, micro-enterprise income refers to the average monthly micro-enterprise income attained during pre- and post-participation in micro-credit and training programs. In India, Panda (2009) showed that there were significant increases in borrowers' household income $(11.41 \%)$ and assets $(9.75 \%)$ which were higher than non-participants. Over in Bangladesh, Alam and Miyagi (2004) reported that micro-credit had effectively contributed $44.49 \%$ in small businesses, $17.73 \%$ in livestock earnings, $12.74 \%$ in agriculture, and $4.84 \%$ in the fisheries sector. Finally, Al-Mamun, Malarvizhi, Hussain and Tan's (2012) study on the effect of AIM micro-credit programs had reported significant increases in enterprise and household incomes after participants benefitted from the micro-credit and training programs. Although the positive impact of micro-credit and training programs on income generating activities is evident, yet the effectiveness is dependent upon the households' ability to utilize micro-credit in a way that increases micro-enterprise income and assets over time. However, the study by Kozulbikova et al (2015) mention that the mismanagement of cash flows or insufficient management of financial risk is the most common failured for business. The objective of this study is to examine the impact of access to working capital and training programs on microenterprise income among the participants of various development organization (i.e. AIM, TEKUN, and LKIM) in Kelantan, Malaysia. Thus, the following specific hypothesis is examined: 
Hypothesis 1: Access to working capital and enterprise development training programs lead to an increase in micro-enterprise income among the participants of development organizations in Malaysia.

\section{Impact on Micro-Enterprise Growth}

Micro-enterprise income, assets, and performance are considered key determinants of micro-enterprise growth. Studies conducted to measure the effectiveness of micro-credit and training programs provided by development organizations generally focused on how participation effects participant's income and assets that lead to an increase in microenterprise growth. Income and assets are important indicators of household economic wellbeing and are considered to be more stable over time (Al-Mamun, Adaikalam \& Mazumder, 2012). Al-Mamun, Adaikalam, and Mazumder (2012) also highlighted that micro-credit enables micro-entrepreneurs to better manage existing assets, to undertake risks and reduce liabilities. Latifee (2003) mentioned that about $90 \%$ of participants reported an improvement in the standard of living corresponding with a reduction in the poverty rate, where over $46 \%$ of the participants had crossed the poverty line. Also, Sebstad and Walsh (1991) reported the positive impacts of micro-credit on micro-enterprise income, assets, and performance. This was followed by Uotila's (2005) study that reported that participation in the micro-credit program increased participants' enterprise income, household income, assets, and level of household's welfare over time. Dunn's (2005) study in Bosnia and Herzegovina reported the same findings which indicated a significant positive impact of micro-credit on income and business investments. Finally, Dunn and Arbuckle's (2001) Peru study found that there were significant increases in micro-enterprise income and assets among the participants as compared to non-participants in micro-credit programs. Therefore, this study examined the impacts of access to working capital and training programs among the participants of various development organizations (i.e. AIM, TEKUN, and LKIM) in Kelantan, Malaysia that lead to an increase in micro-enterprise growth. Thus, the following specific hypothesis is investigated:

Hypothesis 2: Access to working capital and enterprise development training programs lead to an increase in micro-enterprise growth among the participants of development organizations in Malaysia.

\section{Impact on Micro-Enterprise Assets}

To survive in a constantly changing business environment, securing and stabilizing micro-enterprise income, assets and performance become key to sustained growth. Thus, micro-credit and training programs become essential tools for micro-enterprises to spur income generation and asset accumulation (Al-Mamun, Adaikalam \& Mazumder, 2012). This study examined micro-enterprise assets as a dependent variable as asset performance is reflected against long-term income flows, hence is considered a viable socio-economic indicator (Barnes, 1996). When micro-entrepreneurs utilized micro-credit for asset accumulation, the asset incremental impact is directly evident (Al-Mamun, Adaikalam \& Mazumder, 2012). The behavior of asset accumulation and liability reduction indicates a strategy employed by micro-entrepreneurs in managing risks (Barnes, 1996).

Hossain (1988) reported that participants with more than a three-year membership increased the fixed asset to about 2.5 times higher compared to those who just joined microcredit and training programs. Meanwhile, Sutoro (1990) reported that participant's enterprise income increment of $93 \%$ had spurred increments in the ownership of productive machinery 
by $26 \%$, in the ownership of the business vehicle by $16 \%$, and of household's income by 76\%. Also, Barnes (1996) reported that additional assets led to an increase in income and this favorable position had enabled micro-entrepreneurs to better manage existing assets, to undertake risks as a means to decrease economic vulnerability and overcome the poverty trap. The study conducted by Islam (2007) showed that from the working capital received by lowincome micro-entrepreneurs, investment in income and assets had increased. Additionally, the study by Panda (2009) reported that the participant's incremental in both household income of $11.41 \%$ and asset of $9.75 \%$ are higher than non-participants. Finally, Al-Mamun, Adaikalam, and Mazumder (2012) showed that the market value of micro-enterprise assets owned by the existing participants was higher than the new participants, thus indicating a positive effect of micro-credit programs on micro-enterprise assets. The objective of this study is to examine the impacts of access to working capital and training programs on micro-enterprise assets among participants of various development organizations (i.e. AIM, TEKUN, and LKIM) in Kelantan, Malaysia. Thus, the following specific hypothesis is investigated:

Hypothesis 3: Access to working capital and enterprise development training programs lead to an increase in micro-enterprise assets among the participants of development organizations in Malaysia.

\section{Research Methodology}

This study employed a cross-sectional design to deploy face-to-face structured interview to collect quantitative data in an attempt to assess the impacts of access to working capital and enterprise development training programs on Kelantanese micro-enterprise income, growth, and asset net worth. The population of this study refers to a total of 88,435 low-income micro-entrepreneurs identified as participants of development program initiated by AIM, TEKUN and LKIM in Kelantan, Malaysia. The research team obtained three randomly selected list of participants from three development organizations, i.e., a list of 500 low-income micro-entrepreneurs from AIM Kelantan; a list of 350 low-income microentrepreneurs from TEKUN Kelantan, and a list of 156 low-income micro-entrepreneurs from LKIM Kelantan. The total of 1,006 participants was located in seven districts namely Tumpat, Bachok, Pasir Puteh, Pasir Mas, Tanah Merah, Gua Musang, and Jeli. At the onset of data collection, the research team contacted all 1,006 respondents to explain the purpose of the survey and to secure interview appointments. However, only 450 respondents agreed to be interviewed at their locality.

\section{Sample Size}

For this study, sample size determination was guided by Krejcie and Morgan's (1970) guidelines formula:

$$
\mathrm{S}=\frac{X^{2} N P(1-P)}{d^{2}(N-1)+X^{2} P(1-P)},
$$

where;

$\mathrm{s}=$ required sample size

$\mathrm{X}^{2}=$ the table value of chi-square for 1 degree of freedom at the desired confidence level (3.841.

$\mathrm{N}=$ the population size $(88,435)$

$\mathrm{P}=$ the population proportion (assumed to be 0.50 ) 
$\mathrm{d}=$ the degree of accuracy expressed as a proportion (0.05).

According to Krejcie \& Morgan's (1970) formula, a population of 88,435 requires a sample size of 383 . Therefore, to avoid any possible complication, this study collected data from 450 participants.

\section{Operational Definitions}

Length of participation refers to the enrollment duration of respondents in micro-credit and enterprise development training programs. Numerous scholars showed that the length of participation in micro-credit and training programs appears to have positive effects on microenterprise income and asset throughout the program duration. Researchers found that the investment on fix assets was about 2.5 times higher among participants who clocked-in more than three years of participation compared to new entrants (c.f. Al-Mamun, Abdul Wahab \& Malarvizhi, 2010; Dunn, 2005; Panda, 2009; Salma, 2004; Singh, 2009).

Next, the total amount of economic loan received refers to the number of working capital participants had received from AIM, TEKUN, and LKIM. Researchers reported a positive relationship between the amount of economic loan received and micro-enterprise income, is effectively reflected by the addition of new products and/or services, improved and/or expanded micro-enterprise activities, and the increase of enterprise asset (c.f. AlShami, Razali \& Rashid, 2017; Ariful, Atanu \& Ashiqur, 2017; Claessens \& Tzioumis, 2006)

Meanwhile, training hours refers to the total attendance in the number of enterprise development training programs, a number of training hours, and number of centre meetings and/or discussions, reported within the last 12 months.. The outcome of a low profitability loan invested in business was contributed by the lack of business skills in managing new income generating activities (c.f. Copestake, Bhalotra \& Johnson, 2001; Geta \& Hamiso, 2017; Hietalahti \& Linden, 2006; Samer et al., 2015).

This study also measured the impacts on micro-enterprise income and assets, and to ensure impact confirmation, measurements on changes in micro-enterprise income and assets as dependent variables were included. Micro-enterprise income refers to the changes in the average monthly income: post-participation average monthly income (last twelve months) minus pre-participation average monthly income (last twelve months). Meanwhile, microenterprise assets refer to the changes in micro-enterprise asset net worth post-participation (includes the approximate market value of vehicle, machinery, raw materials, and finished goods).

\section{Control Variables}

This study expected other variables to affect micro-enterprise income, growth and assets, specifically education, household size, household income, and micro-enterprise asset net worth. The above variables were expected to affect micro-enterprise income, growth, and assets in different ways, thus we considered several assumptions. For the education variable, this study applied the assumption that the higher the level of education, the less vulnerable the participants are. In terms of household size, this study adopted the assumption that the larger the household size, the higher is the demand loan or income. Whereas the assumption on household income is that participants who already owned assets prior to micro-credit program participation have the tendency to continue to increase household income for the purpose of further asset accumulation at post-participation, and these participants also earn more household income than those who do not own any assets. This study also considered the assumption on micro-enterprise asset net worth where the increase in micro-enterprise income 
is followed by an increase in a micro-enterprise asset, thus suggesting the possibility for lowincome micro-entrepreneurs to earn a business profit for asset accumulation. Previous studies found that education (Mahmood, Hussain \& Matlay, 2014; Okojie et al., 2009), household size (Asghar. 2012; Sayvaya \& Kyophilaving, 2015;), household income (Ellertsson, 2012; Saad \& Duasa, 2011), and micro-enterprise asset net worth (Asghar, 2012; Ellertsson, 2012; Kasali et al., 2016) affected micro-enterprise income, growth, and assets among participants of various development initiatives in Kelantan, Malaysia. Among the selected variables, this study assessed the effect of gender by assigning a value for Male as ' 1 ' and Female as ' 0 '; assuming that gender of the borrowers has an effect on micro-enterprise income, growth, and assets.

\section{Data Analysis}

The data were analysed by using the Statistical Package for Social Science (SPSS) in an easy to understand format for interpretation and tabulation. Multiple regression analysis was performed to establish the relationship between micro-enterprise income, assets and venture growth with participation in the development initiatives among the low-income micro-entrepreneurs in Kelantan, Malaysia. Partial correlation analysis was conducted to determine the relationship linked to controlling the effect of selected antecedents. Finally, this study was used multiple regression analysis to assess the effect of participation on microenterprise income, asset and venture growth. Typically, the presence of outliers ought to be high in such study genres due to the relatively higher variation in the distribution. Hence, the model was tested for multivariate normality to discard outliers. After that, the model was tested again to verify that the original findings and significances were not significances affected by the absence of multivariate normality.

\section{Summary of Findings}

\section{Demographic Characteristics}

The data were collected in December 2017 from 450 low-income micro-entrepreneurs operating in the state of Kelantan, Malaysia. This cohort consisted of 224 (49.8\%) males and $226(50.2 \%)$ females. The majority of respondents were in the age range of 41 to 50 years old (200 respondent, or 44.4\%), followed by 125 (27.8\%) who were between 51 and 60 years old. Another $64(14.2 \%)$ respondents were between 31 and 40 years old, and 40 (8.9\%) respondents were 61 years old and above. Only $21(4.7 \%)$ respondents were 30 years old and below.

In terms of prior entrepreneurial experience, 300 (66.7\%) respondents reported zero experience micro-enterprise management. This was followed by $113(22.5 \%)$ respondents with 1 to 5 years of experience, while $25(5.5 \%)$ respondents had 6 to 10 years, and only 12 $(2.5 \%)$ respondents had more than 10 years of experience. In terms of government support, only $55(12.2 \%)$ from the 450 respondents received government support while the other 395 $(87.8 \%)$ had not received any. With regards to the number of employees, a total of 273 $(60.7 \%)$ respondents hired 3 to 4 employees, followed by 102 (22.6\%) respondents who hired more than 5 employees, while $73(16.2 \%)$ respondents engaged 2 employees, and only 2 $(0.4 \%)$ respondents had none. 
Table 1. Profile of the Respondent

\begin{tabular}{|c|c|c|c|c|c|}
\hline & $\mathrm{n}$ & $\%$ & & $\mathrm{n}$ & $\%$ \\
\hline Gender & & & Number of Employees & & \\
\hline Male & 224 & 49.8 & None & 2 & 0.4 \\
\hline Female & 226 & 50.2 & Up to 2 Employees & 73 & 16.2 \\
\hline \multirow[t]{2}{*}{ Total } & 450 & 100.0 & 3 to 4 Employees & 273 & 60.7 \\
\hline & & & 5 and above & 102 & 22.6 \\
\hline Age & & & Total & 450 & 100.0 \\
\hline Up to 30 years old & 21 & 4.7 & & & \\
\hline 31 years old-40 years old & 64 & 14.2 & Firm Established & & \\
\hline 41 years old- 50 years old & 200 & 44.4 & 1 to 5 Years & 52 & 11.6 \\
\hline 51 years old-60 years old & 125 & 27.8 & 6 to 10 Years & 192 & 42.7 \\
\hline 61 years old and above & 40 & 8.9 & 11 to 15 Years & 144 & 32.0 \\
\hline \multirow[t]{2}{*}{ Total } & 450 & 100.0 & 16 to 20 Years & 60 & 13.3 \\
\hline & & & 21 Years and Above & 2 & 0.4 \\
\hline Prior Entrepreneurial Experience & & & Total & 450 & 100.0 \\
\hline None & 300 & 66.7 & & & \\
\hline 1 to 5 Years & 113 & 22.5 & Types of Firm & & \\
\hline 6 to 10 Years & 25 & 5.5 & Manufacturing & 52 & 11.6 \\
\hline More than 10 Years & 12 & 2.5 & Retailing & 80 & 17.8 \\
\hline \multirow[t]{2}{*}{ Total } & 450 & 100.0 & Service & 266 & 59.1 \\
\hline & & & Livestock & 17 & 3.8 \\
\hline Received government support & & & Wholesaling & 2 & 0.4 \\
\hline No & 395 & 87.8 & Fishing & 33 & 7.3 \\
\hline Yes & 55 & 12.2 & Total & 450 & 100.0 \\
\hline
\end{tabular}

Source: Author(s) own compilation

With regards to the number of years established, $192(42.7 \%)$ respondents established their micro-enterprise 6 to 10 years ago, followed by $144(32.0 \%)$ that had established their enterprise 11 to 15 years ago. Another $60(13.3 \%)$ respondents established their enterprise 16 to 20 years ago, and 52 or $11.6 \%$ had established their enterprise only 1 to 5 years ago. Only 2 $(0.4 \%)$ respondents had a micro-enterprise established for more than 21 years. The sectoral breakdown of the 450 respondents is as follows: $266(59.1 \%)$ in the services sector; 80 $(17.8 \%)$ in retail; $52(11.6 \%)$ in manufacturing; $33(7.3 \%)$ in fisheries; $17(3.8 \%)$ in the livestock; and $2(0.4 \%)$ in the wholesale sector.

\section{Descriptive Analysis}

Table 2 presents the mean value for the average monthly household income at RM1,834.75 with a standard deviation of RM865.74. The mean value for the pre-participation annual micro-enterprise income was RM7,894.44 with a standard deviation of RM4,787.54. Next, the mean value for the post-participation annual micro-enterprise income was RM19,251.78 with a standard deviation of RM9,748.52. Meanwhile, the mean value for changes in annual micro-enterprise income was RM11,357.33 with a standard deviation of RM6,873.19, while the mean value for the change in monthly micro-enterprise income was RM946.44 with a standard deviation of RM572.76.

Table 2 also reports that the mean value for the approximate market value of preparticipation micro-enterprise assets was at RM10,598.78 with a standard deviation of RM5319.01. Subsequently, the mean value for the post-participation approximate market value of enterprise assets was RM29,295.63 with a standard deviation of RM12,282.23. The mean value for the change in the approximate market value for micro-enterprise assets was RM18,696.84 with a standard deviation of RM9,637.29. 
Table 2. Respondents and Participation Details

\begin{tabular}{lcccc}
\hline & Minimum & Maximum & Mean & Std. Dev. \\
\hline Average Monthly Household Income & 100 & 3583 & 1834.75 & 865.74 \\
\hline Yearly Micro-Enterprise Income (Before) & 0 & 28000 & 7894.44 & 4787.54 \\
\hline Yearly Micro-Enterprise Income (After) & 800 & 40000 & 19251.78 & 9748.52 \\
\hline Changes in Micro-Enterprise Income (Yearly) & 0.00 & 38000.00 & 11357.33 & 6873.19 \\
\hline Changes in Micro-Enterprise Income (Average Monthly) & 0.00 & 3166.67 & 946.44 & 572.76 \\
\hline Approximate market value of Enterprise Assets (Before) & 0 & 21000 & 10598.78 & 5319.01 \\
\hline Approximate market value of Enterprise Assets (After) & 2000 & 50000 & 29295.63 & 12282.23 \\
\hline Changes in Approximate market value of Enterprise Assets & .00 & 50000.00 & 18696.84 & 9637.29 \\
\hline Cumulative Growth (approximate): Sales (\%) & 10 & 100 & 58.06 & 16.58 \\
\hline Cumulative Growth (approximate): Employment (\%) & 10 & 100 & 53.74 & 14.04 \\
\hline Cumulative Growth (approximate): Profit (\%) & 10 & 100 & 57.96 & 13.77 \\
\hline Cumulative Venture Growth (approximate) (\%) & 10.00 & 96.67 & 56.58 & 11.67 \\
\hline Number of Years & 1 & 22 & 10.87 & 4.43 \\
\hline The total amount of economic loan received & 1000 & 95000 & 21454.44 & 11167.23 \\
\hline Total number of training programs attended & 0 & 16 & 5.50 & 2.77 \\
\hline Total number of training hours & 0 & 180 & 40.47 & 22.87 \\
\hline Number of Centre Meeting or Discussion & 0 & 48 & 32.77 & 20.94 \\
\hline Age & 19 & 77 & 48.31 & 9.619 \\
\hline Education (Number of Years in School) & 0 & 15 & 5.82 & 3.560 \\
\hline Household Size & 2 & 17 & 7.80 & 1.742 \\
\hline Number of Gainfully Employed Members & 1 & 8 & 2.91 & 1.132 \\
\hline Number of Dependent Members & 0 & 11 & 4.91 & 1.814 \\
\hline Total Number Sources of Income & 1 & 3 & 1.08 & .286 \\
\hline Sorce & & &
\end{tabular}

Source: Author(s) own compilation

In addition, Table 2 reports micro-enterprise growth. The mean value of the approximate cumulative growth in sales was $58.06 \%$ and the standard deviation was $16.58 \%$, while the mean value of the approximate cumulative growth in employment was $53.74 \%$ with a standard deviation of $14.04 \%$, whereas and the mean value of the approximate cumulative growth in profit was $57.96 \%$ with a standard deviation of $13.77 \%$. The mean value for the approximate cumulative venture growth was $56.58 \%$ where the standard deviation was $11.67 \%$.

Next, Table 2 presents results on participation. The mean number of years in development programs was 10.87 years with a standard deviation of 4.43 years. The mean for the total amount of economic loans received was RM21,454.44 with a standard deviation of RM11,167.23. Meanwhile, the mean value for the total number of training programs was 5.50 programs with a standard deviation of 2.77 programs, while the total number of training hours has a mean of 40.47 hours with a standard deviation of 22.87 hours. Also, the total number of centre meetings and/or discussions attended was 32.77 times with a standard deviation of 20.94 times.

Finally, Table 2 presents the participants' demographic results. The mean age of the respondents was 48.31 years with a standard deviation of 9.619 years, while the mean value of the number of schooling years was 5.82 years with a standard deviation of 3.560 years. The mean value for household size was 7.80 members with a standard deviation of 1.742 members. The mean value of the number of gainfully employed members was 2.91 members with a standard deviation of 1.132 members. In addition, the mean value for the number of dependent members was 4.91 members with a standard deviation of 1.814 members, and the mean value for the total number of sources of income was 1.08 sources with a standard deviation of 0.286 sources. 
Table 3. Length of Participation and Key Determinants

\begin{tabular}{|c|c|c|c|c|c|}
\hline & & $\mathrm{N}$ & Mean & Std. Dev. & Sig. \\
\hline \multirow{5}{*}{$\begin{array}{l}\text { Yearly Micro-Enterprise } \\
\text { Income (Before) }\end{array}$} & $1-5$ years & 45 & 9277.78 & 5779.62 & \multirow{5}{*}{.047} \\
\hline & 6-10 Years & 193 & 8015.54 & 3282.12 & \\
\hline & 11-15 Years & 139 & 7869.06 & 5748.11 & \\
\hline & 16 Years and Above & 73 & 6769.86 & 5286.61 & \\
\hline & Total & 450 & 7894.44 & 4787.54 & \\
\hline \multirow{5}{*}{$\begin{array}{l}\text { Yearly Micro-Enterprise } \\
\text { Income (After) }\end{array}$} & $1-5$ years & 45 & 20644.44 & 10075.07 & \multirow{5}{*}{.665} \\
\hline & 6-10 Years & 193 & 19432.12 & 7403.83 & \\
\hline & $11-15$ Years & 139 & 18963.31 & 11955.41 & \\
\hline & 16 Years and Above & 73 & 18465.75 & 10411.10 & \\
\hline & Total & 450 & 19251.78 & 9748.52 & \\
\hline \multirow{5}{*}{$\begin{array}{l}\text { Changes in Micro-Enterprise } \\
\text { Income (Yearly) }\end{array}$} & $1-5$ years & 45 & 11366.66 & 6533.48 & \multirow{5}{*}{.942} \\
\hline & 6-10 Years & 193 & 11416.58 & 5930.28 & \\
\hline & 11-15 Years & 139 & 11094.24 & 8035.31 & \\
\hline & 16 Years and Above & 73 & 11695.89 & 7121.74 & \\
\hline & Total & 450 & 11357.33 & 6873.19 & \\
\hline \multirow{5}{*}{$\begin{array}{l}\text { Changes in the Approximate } \\
\text { market value of Enterprise } \\
\text { Assets }\end{array}$} & $1-5$ years & 45 & 14676.22 & 8163.43 & \multirow{5}{*}{.000} \\
\hline & 6-10 Years & 193 & 21719.68 & 9136.90 & \\
\hline & 11-15 Years & 139 & 16665.03 & 9147.04 & \\
\hline & 16 Years and Above & 73 & 17052.19 & 10496.33 & \\
\hline & Total & 450 & 18696.84 & 9637.29 & \\
\hline \multirow{5}{*}{$\begin{array}{l}\text { Cumulative Venture Growth } \\
\text { (approximate) }(\%)\end{array}$} & $1-5$ years & 45 & 54.52 & 14.57 & \multirow{5}{*}{.021} \\
\hline & 6-10 Years & 193 & 56.73 & 9.95 & \\
\hline & 11-15 Years & 139 & 55.23 & 11.33 & \\
\hline & 16 Years and Above & 73 & 60.03 & 13.82 & \\
\hline & Total & 450 & 56.58 & 11.67 & \\
\hline
\end{tabular}

Source: Author(s) own compilation

As presented in Table 3, the pre-participation annual micro-enterprise income, postparticipation annual micro-enterprise income, change in the annual micro-enterprise income, as well as change in the approximate market value of micro-enterprise assets, and the approximate cumulative venture growth were grouped based on the length of participation. Thus, the mean pre-participation annual micro-enterprise income across the groups shows that new participants' pre-participation micro-enterprise income was relatively higher than that of existing participants. Similarly, the mean post-participation annual micro-enterprise income across the groups shows that new participants' post-participation micro-enterprise income was relatively higher than that of existing participants. As for the changes in annual microenterprise income, respondents who participated for 6 to 10 years reported a relatively higher micro-enterprise income increment than that of other groups. Moreover, respondents who participated for 6 to 10 years also reported a relatively higher micro-enterprise asset net worth than that of other groups. Finally, the cumulative venture growth among the respondents who have been participating for 16 years and more was relatively higher than that of other groups.

In Table 4, the pre-participation annual micro-enterprise income, post-participation annual micro-enterprise income, change in annual micro-enterprise income, change in the approximate market value of micro-enterprise assets and approximate cumulative venture growth, were grouped based on the number of training programs attended by the respondent. Findings revealed that respondents who attended a total of 5 to 8 enterprise development training programs secured a relatively higher amount of pre-participation annual microenterprise income, post-participation annual micro-enterprise income, change in postparticipation annual micro-enterprise income, and micro-enterprise asset net worth than that of other respondents. 
Table 4. Training and Key Determinants

\begin{tabular}{|c|c|c|c|c|c|}
\hline & & $\mathrm{N}$ & Mean & Std. Dev. & Sig. \\
\hline \multirow{6}{*}{$\begin{array}{l}\text { Yearly Micro-Enterprise } \\
\text { Income (Before) }\end{array}$} & Up to 2 ED Trainings & 50 & 7798.00 & 7523.39 & \multirow{6}{*}{.782} \\
\hline & 3 to 4 Trainings & 152 & 7608.55 & 4793.22 & \\
\hline & 5 to 6 Trainings & 154 & 8216.23 & 3634.34 & \\
\hline & 7 to 8 Trainings & 20 & 8550.00 & 2665.07 & \\
\hline & More than 9 Training & 74 & 7700.00 & 5037.63 & \\
\hline & Total & 450 & 7894.44 & 4787.54 & \\
\hline \multirow{6}{*}{$\begin{array}{l}\text { Yearly Micro-Enterprise } \\
\text { Income (After) }\end{array}$} & Up to 2 ED Trainings & 50 & 18504.00 & 14709.34 & \multirow{6}{*}{.660} \\
\hline & 3 to 4 Trainings & 152 & 18919.08 & 9839.31 & \\
\hline & 5 to 6 Trainings & 154 & 20103.90 & 7911.20 & \\
\hline & 7 to 8 Trainings & 20 & 20250.00 & 6927.25 & \\
\hline & More than 9 Training & 74 & 18397.30 & 9602.71 & \\
\hline & Total & 450 & 19251.78 & 9748.52 & \\
\hline \multirow{6}{*}{$\begin{array}{l}\text { Changes in Micro-Enterprise } \\
\text { Income (Yearly) }\end{array}$} & Up to 2 ED Trainings & 50 & 10706.00 & 8121.23 & \multirow{6}{*}{.718} \\
\hline & 3 to 4 Trainings & 152 & 11310.52 & 6898.14 & \\
\hline & 5 to 6 Trainings & 154 & 11887.66 & 6549.88 & \\
\hline & 7 to 8 Trainings & 20 & 11700.00 & 5037.75 & \\
\hline & More than 9 Training & 74 & 10697.29 & 7069.73 & \\
\hline & Total & 450 & 11357.33 & 6873.19 & \\
\hline \multirow{6}{*}{$\begin{array}{l}\text { Changes in the Approximate } \\
\text { market value of Enterprise } \\
\text { Assets }\end{array}$} & Up to 2 ED Trainings & 50 & 12883.60 & 6857.88 & \multirow{6}{*}{.000} \\
\hline & 3 to 4 Trainings & 152 & 19014.27 & 10334.84 & \\
\hline & 5 to 6 Trainings & 154 & 20002.27 & 9113.03 & \\
\hline & 7 to 8 Trainings & 20 & 21299.00 & 8406.30 & \\
\hline & More than 9 Training & 74 & 18552.70 & 9873.16 & \\
\hline & Total & 450 & 18696.84 & 9637.29 & \\
\hline \multirow{6}{*}{$\begin{array}{l}\text { Cumulative Venture Growth } \\
\text { (approximate) }(\%)\end{array}$} & Up to 2 ED Trainings & 50 & 53.76 & 11.99 & \multirow{6}{*}{.426} \\
\hline & 3 to 4 Trainings & 152 & 57.41 & 12.44 & \\
\hline & 5 to 6 Trainings & 154 & 56.67 & 10.77 & \\
\hline & 7 to 8 Trainings & 20 & 57.53 & 8.73 & \\
\hline & More than 9 Training & 74 & 56.33 & 12.27 & \\
\hline & Total & 450 & 56.58 & 11.67 & \\
\hline
\end{tabular}

Source: Author(s) own compilation

Table 5. Training Hours and Key Determinants

\begin{tabular}{|c|c|c|c|c|c|}
\hline & & $\mathrm{N}$ & Mean & Std. Dev. & Sig. \\
\hline \multirow{5}{*}{$\begin{array}{l}\text { Yearly Micro-Enterprise } \\
\text { Income (Before) }\end{array}$} & Up to 20 Hours & 77 & 7500.00 & 6221.52 & \multirow{5}{*}{.075} \\
\hline & 21 to 40 Hours & 176 & 7484.09 & 4273.34 & \\
\hline & 41 to 60 Hours & 113 & 7927.43 & 4053.37 & \\
\hline & More than 60 Hours & 84 & 9071.43 & 5096.15 & \\
\hline & Total & 450 & 7894.44 & 4787.54 & \\
\hline \multirow{5}{*}{$\begin{array}{l}\text { Yearly Micro-Enterprise } \\
\text { Income (After) }\end{array}$} & Up to 20 Hours & 77 & 17572.73 & 12437.34 & \multirow{5}{*}{.005} \\
\hline & 21 to 40 Hours & 176 & 18476.14 & 8731.35 & \\
\hline & 41 to 60 Hours & 113 & 19199.12 & 8052.15 & \\
\hline & More than 60 Hours & 84 & 22486.90 & 10475.61 & \\
\hline & Total & 450 & 19251.78 & 9748.52 & \\
\hline \multirow{5}{*}{$\begin{array}{l}\text { Changes in Micro-Enterprise } \\
\text { Income (Yearly) }\end{array}$} & Up to 20 Hours & 77 & 10072.72 & 7353.36 & \multirow{5}{*}{.013} \\
\hline & 21 to 40 Hours & 176 & 10992.04 & 6574.62 & \\
\hline & 41 to 60 Hours & 113 & 11271.68 & 6099.94 & \\
\hline & More than 60 Hours & 84 & 13415.47 & 7654.04 & \\
\hline & Total & 450 & 11357.33 & 6873.19 & \\
\hline \multirow{5}{*}{$\begin{array}{l}\text { Changes in the Approximate } \\
\text { market value of Enterprise } \\
\text { Assets }\end{array}$} & Up to 20 Hours & 77 & 15534.28 & 8369.64 & \multirow{5}{*}{.001} \\
\hline & 21 to 40 Hours & 176 & 18566.42 & 9456.81 & \\
\hline & 41 to 60 Hours & 113 & 21180.70 & 9966.15 & \\
\hline & More than 60 Hours & 84 & 18527.73 & 9897.41 & \\
\hline & Total & 450 & 18696.84 & 9637.29 & \\
\hline \multirow{2}{*}{$\begin{array}{l}\text { Cumulative Venture Growth } \\
\text { (approximate) }(\%)\end{array}$} & Up to 20 Hours & 77 & 55.3593 & 12.10 & \\
\hline & 21 to 40 Hours & 176 & 57.2311 & 11.33 & \\
\hline
\end{tabular}




\begin{tabular}{lcccc}
\hline 41 to 60 Hours & 113 & 56.1593 & 10.91 & .659 \\
More than 60 Hours & 84 & 56.9246 & 12.97 & \\
Total & 450 & 56.5844 & 11.67 & \\
\hline
\end{tabular}

Source: Author(s) own compilation

Table 6. Loan Received and Key Determinants

\begin{tabular}{|c|c|c|c|c|c|}
\hline & & $\mathrm{N}$ & Mean & Std. Dev. & Sig. \\
\hline \multirow{5}{*}{$\begin{array}{l}\text { Yearly Micro-Enterprise } \\
\text { Income (Before) }\end{array}$} & Up to $10 \mathrm{k}$ & 66 & 6234.85 & 6384.32 & \multirow{5}{*}{.002} \\
\hline & $11 \mathrm{k}$ to $20 \mathrm{k}$ & 195 & 7648.21 & 4505.79 & \\
\hline & $21 \mathrm{k}$ to $30 \mathrm{k}$ & 115 & 8686.96 & 4443.33 & \\
\hline & $31 \mathrm{~K}$ and Above & 74 & 8791.89 & 3929.47 & \\
\hline & Total & 450 & 7894.44 & 4787.54 & \\
\hline \multirow{5}{*}{$\begin{array}{l}\text { Yearly Micro-Enterprise } \\
\text { Income (After) }\end{array}$} & Up to $10 \mathrm{k}$ & 66 & 15284.85 & 12803.66 & \multirow{5}{*}{.000} \\
\hline & $11 \mathrm{k}$ to $20 \mathrm{k}$ & 195 & 18769.23 & 9125.80 & \\
\hline & $21 \mathrm{k}$ to $30 \mathrm{k}$ & 115 & 20691.30 & 8656.85 & \\
\hline & $31 \mathrm{~K}$ and Above & 74 & 21824.32 & 8682.14 & \\
\hline & Total & 450 & 19251.78 & 9748.52 & \\
\hline \multirow{5}{*}{$\begin{array}{l}\text { Changes in Micro-Enterprise } \\
\text { Income (Yearly) }\end{array}$} & Up to $10 \mathrm{k}$ & 66 & 9050.00 & 8237.68 & \multirow{5}{*}{.004} \\
\hline & $11 \mathrm{k}$ to $20 \mathrm{k}$ & 195 & 11121.02 & 6726.49 & \\
\hline & $21 \mathrm{k}$ to $30 \mathrm{k}$ & 115 & 12004.34 & 6017.69 & \\
\hline & $31 \mathrm{~K}$ and Above & 74 & 13032.43 & 6699.31 & \\
\hline & Total & 450 & 11357.33 & 6873.19 & \\
\hline \multirow{5}{*}{$\begin{array}{l}\text { Changes in the Approximate } \\
\text { market value of Enterprise } \\
\text { Assets }\end{array}$} & Up to $10 \mathrm{k}$ & 66 & 14161.06 & 10483.87 & \multirow{5}{*}{.000} \\
\hline & $11 \mathrm{k}$ to $20 \mathrm{k}$ & 195 & 17980.15 & 9546.30 & \\
\hline & $21 \mathrm{k}$ to $30 \mathrm{k}$ & 115 & 21250.95 & 8989.68 & \\
\hline & $31 \mathrm{~K}$ and Above & 74 & 20661.62 & 8416.72 & \\
\hline & Total & 450 & 18696.84 & 9637.29 & \\
\hline \multirow{5}{*}{$\begin{array}{l}\text { Cumulative Venture Growth } \\
\text { (approximate) }(\%)\end{array}$} & Up to $10 \mathrm{k}$ & 66 & 53.61 & 13.91 & \multirow{5}{*}{.032} \\
\hline & $11 \mathrm{k}$ to $20 \mathrm{k}$ & 195 & 56.24 & 11.54 & \\
\hline & $21 \mathrm{k}$ to $30 \mathrm{k}$ & 115 & 57.10 & 10.52 & \\
\hline & $31 \mathrm{~K}$ and Above & 74 & 59.32 & 11.03 & \\
\hline & Total & 450 & 56.58 & 11.67 & \\
\hline
\end{tabular}

Source: Author(s) own compilation

As presented in Table 5, the pre-participation annual micro-enterprise income, postparticipation annual micro-enterprise income, change in annual micro-enterprise income, change in the approximate market value of micro-enterprise asset net worth, and approximate cumulative venture growth, were grouped in the number of training hours attended by the respondents. Findings revealed that respondents who attended more than 60 hours of enterprise development training programs also secured a relatively higher amount of pre- and post-participation annual micro-enterprise incomes, change in post-participation annual micro-enterprise income and cumulative venture growth than that of other respondents.

As presented in Table 6, the annual pre-participation micro-enterprise income, postparticipation annual micro-enterprise income, change in annual micro-enterprise income, change in the approximate market value of micro-enterprise assets and approximate cumulative venture growth were grouped based on the total amount of economic loans received. Findings revealed that respondents who received economic loans of RM31,000 and more also attained a relatively higher amount of pre- and post- participation annual microenterprise income, change in post-participation micro-enterprise income, and cumulative venture growth than that of other respondents. 
Table 7. Partial Correlation

\begin{tabular}{|c|c|c|c|c|c|c|c|c|c|}
\hline Variables & & Income & Assets & Growth & Year & Training & Hours & $\mathrm{CM} / \mathrm{D}$ & Loan \\
\hline & Correlation & 1.000 & & & & & & & \\
\hline \multirow[t]{2}{*}{ Income } & Sig. (1-tailed) & & & & & & & & \\
\hline & Correlation & .069 & 1.000 & & & & & & \\
\hline \multirow[t]{2}{*}{ Assets } & Sig. (1-tailed) & .074 & & & & & & & \\
\hline & Correlation & .644 & .042 & 1.000 & & & & & \\
\hline \multirow[t]{2}{*}{ Growth } & Sig. (1-tailed) & .000 & .190 & & & & & & \\
\hline & Correlation & .138 & .206 & .081 & 1.000 & & & & \\
\hline \multirow[t]{2}{*}{ Year } & Sig. (1-tailed) & .002 & .000 & .043 & & & & & \\
\hline & Correlation & -.036 & -.032 & .045 & .026 & 1.000 & & & \\
\hline \multirow[t]{2}{*}{ Training } & Sig. (1-tailed) & .224 & 247 & .171 & 289 & & & & \\
\hline & Correlation & -.034 & .039 & .023 & .099 & .786 & 1.000 & & \\
\hline \multirow[t]{2}{*}{ Hours } & Sig. (1-tailed) & .234 & .204 & .314 & .018 & .000 & & & \\
\hline & Correlation & -.029 & -.242 & .089 & -.439 & .339 & .231 & 1.000 & \\
\hline \multirow{2}{*}{$\mathrm{CM} / \mathrm{D}$} & Sig. (1-tailed) & .270 & .000 & .029 & .000 & .000 & .000 & & \\
\hline & Correlation & -.028 & -.100 & .113 & -.150 & .355 & 277 & .329 & 1.000 \\
\hline Loan & Sig. (1-tailed) & .277 & .017 & .008 & .001 & .000 & .000 & .000 & \\
\hline
\end{tabular}

Note: (a) Income - Changes in Micro-Enterprise Income (Average Monthly); Assets - Changes in Approximate market value of Enterprise Assets; Growth - Cumulative Venture Growth (approximate) (\%); Years - Number of years; Training - Number of Training Programs Attended, Hours - Number of Hours of Training Programs, CM/D - Number of Centre Meeting or Discussion, and Loan - Total amount of economic loan received

(b) Control variables - Age, Education (Number of Years in School), Household Size, Number of Gainfully Employed Members, Number of Dependent Members, and Total Number Sources of Income

Source: Author(s) own compilation

\section{Partial Correlations}

Partial correlation was conducted to determine the relationship between the changes in micro-enterprise income, assets, growth, and the participation indicators. The findings in Table 6 showed that the number of years of participation had a positive and statistically significant correlation with the changes in micro-enterprise income, changes in microenterprise asset net-worth, and cumulative venture growth; controlling the effect of respondent's age, education (number of schooling years), household size, number of gainfully employed members, number of dependent members, and total number of sources of income. The total amount of economic loans received also had a positive and statistically significant relationship with cumulative venture growth; controlling the effect of respondent's age, education (number of schooling years), household size, number of gainfully employed members, number of dependent members, and the total number of sources of income.

\section{Impact on Micro-Enterprise Income}

The VIF values were below 5, and the tolerance values were below 2, thus indicating an absence of multicollinearity issues. The $\mathrm{F}$ and $p$-value from the ANOVA analysis were 9.352 and 0.000 respectively. As the $p$-value for ANOVA statistic was less than 0.001 , it meant that at least one variable can be used to model 'changes in post-participation microenterprise'.However, the Kolmogorov-Smirnov test of normality of the residuals using all respondents $(\mathrm{N}=450)$ resulted in a $p$-value of 0.000 , which was less than 0.05 , thus failed to meet the assumption of normality. The unstandardized residual stem-and-leaf plot presented the outliers based on the unstandardized residual values. This study removed the outliers and reanalyzed the data using 414 respondents. The $p$-value for Kolmogorov-Smirnov test of normality $(\mathrm{N}=414)$ was 0.095 , which was higher than 0.05 , therefore satisfied the assumption of normality. Table 8 presents the standardized beta and $p$-values using 414 respondents. 
After removing the outliers from the 414-respondent dataset, the VIF values were below 5, and the tolerance values were below 2, thus indicated the absence of multicollinearity issues. The $\mathrm{F}$ and $p$-value from the ANOVA analysis were 17.854 and 0.000 respectively. Also, as the $p$-value for the ANOVA analysis was less than 0.001, it meant that at least one variable can be used to model 'changes in post-participation micro-enterprise income'.

Table 8. Impact on Micro-Enterprise Income

\begin{tabular}{lccccc|cc}
\hline & Unst. Beta & $\begin{array}{c}\mathrm{N}=450 \\
\text { Std. Error }\end{array}$ & Stan. Beta & Sig. & VIF & Stan. Beta & Sig. \\
\hline (Constant) & 370.74 & 172.98 & & .033 & & & .101 \\
Years & 12.51 & 6.76 & .097 & .065 & 1.412 & .141 & .005 \\
Training & -41.92 & 15.54 & -.203 & .007 & 2.922 & -.309 & .000 \\
Hours & 5.09 & 1.81 & .204 & .005 & 2.712 & .285 & .000 \\
CM/D & -2.27 & 1.75 & -.083 & .196 & 2.116 & .020 & .751 \\
Loan & .008 & .003 & .151 & .003 & 1.304 & .167 & .001 \\
Education & 23.14 & 8.21 & .144 & .005 & 1.343 & .244 & .000 \\
Household Size & -22.56 & 15.12 & -.069 & .137 & 1.092 & -.113 & .012 \\
NWEA & .014 & .002 & .303 & .000 & 1.367 & .363 & .000 \\
\hline
\end{tabular}

Note: (Dependent variable) Income - Changes in Micro-Enterprise Income (Average Monthly); (Independent Variables) Years - Number of years; Training - Number of Training Programs Attended, Hours - Number of Hours of Training Programs, CM/D - Number of Centre Meeting or Discussion, and Loan - Total amount of economic loan received; (Control variables) Education, Household Size, NWEA - Net Worth of Enterprise Asset (After)

Source: Author(s) own compilation

The findings presented in Table 8 revealed that the number of years of participation in the development initiatives in Kelantan had a positive effect $(\mathrm{N}=450$ and $\mathrm{N}=414)$ on changes of post-participation micro-enterprise income. However, the effect is statistically significant only after removing the outliers $(\mathrm{N}=414)$. Therefore, this study concludes that the length of participation in the development initiatives in Kelantan may lead to an increase in microenterprise income among the participants. As for the effect of the total number of enterprise development training programs and a total number of centre meetings and/or discussions attended by participating micro-entrepreneurs on micro-enterprise income, the outcome was inconclusive. However, the effect of the number of training hours attended by participating micro-entrepreneurs had a significant positive effect $(\mathrm{N}=450$ and $\mathrm{N}=414)$ on micro-enterprise income, which provided sufficient evidence to conclude the positive effect of enterprise development training programs on micro-enterprise income among the participants of the development initiatives in Kelantan.

As for the total amount of economic loan, findings showed a significant ( $p$-value less than 0.05$)$ positive effect $(\mathrm{N}=450$ and $\mathrm{N}=414)$ on changes of post-participation microenterprise income in the development initiatives in Kelantan. Therefore, this study concludes that the total amount of economic loan received leads to an increase in the participant's microenterprise income in Kelantan. As for the effect of control variables, findings revealed a positive and statistically significant effect of education and micro-enterprise asset net worth on the changes of post-participation micro-enterprise income among development initiative participants from low-income micro-entrepreneurs in Kelantan, Malaysia.

\section{Impact on Micro-Enterprise Assets}

The VIF and tolerance values were below 5 and 2 respectively, thus indicated an absence of multicollinearity. The $\mathrm{F}$ and $p$-value from the ANOVA analysis were 19.395 and 0.000 respectively. As the $p$-value for the ANOVA analysis was less than 0.001 , this meant that at least one variable can be used to model 'changes in the approximate market value of 
post-participation micro-enterprise assets'.However, the Kolmogorov-Smirnov test of normality of the residuals using all respondents $(\mathrm{N}=450)$ yielded a $p$-value of 0.000 , which was less than 0.05 hence failed to meet the assumption of normality. The unstandardized residual stem-and-leaf plot presented the outliers based on the unstandardized residual values. This study removed the outliers and reanalyzed the data using 419 respondents. Effectively, the $p$-value for the Kolmogorov-Smirnov test of normality $(\mathrm{N}=419)$ was 0.197 , which was higher than 0.05 , had satisfied the assumption of normality. Table 9 presents the standardized beta and $p$-values using the 419-respondent dataset. After removing the outliers, findings from a total of 419 respondents, the Durbin-Watson statistic of 0.066, which at less than 2 indicated the absence autocorrelation. The VIF and tolerance values were below 5 and 2, respectively, hence indicated the absence of multicollinearity issues. The $\mathrm{F}$ and $p$-value from the ANOVA analysis are 36.676 and 0.000 respectively. As the $p$-value for the ANOVA analysis was less than 0.001, which meant that at least one variable can be used to model 'changes in the approximate market value of post-participation micro-enterprise assets'.

Table 9. Impact on Micro-Enterprise Assets

\begin{tabular}{lccccc|cc}
\hline & \multicolumn{3}{c}{$\mathrm{N}=450$} & & & \multicolumn{2}{c}{$\mathrm{N}=419$} \\
& Unst. Beta & Std. Error & Stan. Beta & Sig. & VIF & Stan. Beta & Sig. \\
\hline (Constant) & 6322.36 & 2168.07 & & .004 & & & .001 \\
Years & 152.06 & 107.67 & .071 & .159 & 1.368 & .107 & .020 \\
Training & -232.92 & 260.95 & -.068 & .373 & 3.187 & -.016 & .810 \\
Hours & 10.58 & 32.58 & .024 & .746 & 3.024 & -.009 & .890 \\
CM/D & 163.98 & 25.74 & .358 & .000 & 1.729 & .501 & .000 \\
Loan & -.004 & .042 & -.005 & .921 & 1.356 & .045 & .322 \\
Education & -205.70 & 134.38 & -.076 & .127 & 1.361 & -.169 & .000 \\
Income & 4.36 & .55 & .367 & .000 & 1.195 & .292 & .000 \\
\hline
\end{tabular}

Note: (Dependent variable) Assets - Changes in Approximate market value of Micro-Enterprise Assets after Participation (Independent Variables) Years - Number of years; Training - Number of Training Programs Attended, Hours - Number of Hours of Training Programs, CM/D - Number of Centre Meeting or Discussion, and Loan - Total amount of economic loan received; (Control variables) Education, Income - Average Monthly Household Income

Source: Author(s) own compilation

The findings presented in Table 9 revealed that years of participation in development initiatives in Kelantan had a positive effect $(\mathrm{N}=450$ and $\mathrm{N}=419)$ on changes of postparticipation micro-enterprise income. However, the effect is statistically significant only after removing the outliers $(\mathrm{N}=419)$. This study, therefore, concludes that the length of participation may lead to an increase in the approximate market value of micro-enterprise assets among the participants of the development initiatives offered in Kelantan Malaysia. However, the effect of the total number of enterprise development training programs and the total number of training hours attended by participating micro-entrepreneurs on microenterprise income remains inconclusive. Yet, the effect of the number of centre meetings and/or discussions attended by participating micro-entrepreneurs had a significant positive effect ( $\mathrm{N}=450$ and $\mathrm{N}=419$ ) on micro-enterprise income. This outcome provided sufficient evidence to conclude the positive effect of centre meetings and/or discussions on the approximate market value of micro-enterprise assets owned by participants of the development programs in Kelantan Malaysia. As for the total amount of economic loan received, the findings remained inconclusive and statistically not significant ( $\mathrm{N}=450$ and $\mathrm{N}=419$ ). There was insufficient evidence to conclude that the total amount of economic loan received can lead to an increase in the approximate market value of micro-enterprise assets 
owned by participants of development initiatives offered in Kelantan. As for the effect of control variables, findings revealed a positive and statistically significant effect of average monthly household income among the participants.

\section{Impact on Venture Growth}

The Kolmogorov-Smirnov test of normality of the residuals using all respondents $(\mathrm{N}=450)$ yielded a $p$-value of 0.023 that was less than 0.05 , hence failed to meet the assumption of normality. The unstandardized residual stem-and-leaf plot presented the outliers based on the unstandardized residual values. This study removed the outliers and reanalyzed the data using 373 respondents. The $p$-value for the Kolmogorov-Smirnov test of normality $(\mathrm{N}=393)$ was 0.200 that was higher than 0.05 , therefore satisfied the assumption of normality. Table 10 presents the standardized beta and $p$-values using the 373 -respondent dataset. After removing the outliers, findings from a total of 373 respondents revealed that the VIF values were below 5 , and the Tolerance values were below 2 , hence indicated that the absence of multicollinearity issues. Effectively, the $\mathrm{F}$ and $p$-value from the ANOVA analysis yielded 2.357 and $0.000(\mathrm{~N} 450)$, and 8.325 and $0.000(\mathrm{~N}=373)$ respectively. As the $p$-values for the ANOVA analysis $(\mathrm{N}=450$ and $\mathrm{N}=373$ ) was less than 0.001 , which meant that at least one variable can be used to model 'venture growth'.

Table 10. Impact on Venture Growth

\begin{tabular}{lccccc|ccc}
\hline & \multicolumn{3}{c}{$\mathrm{N}=450$} & & \multicolumn{3}{c}{$\mathrm{N}=373$} \\
& Unst. Beta & Std. Error & Stan. Beta & Sig. & VIF & Stan. Beta & Sig. \\
\hline (Constant) & 51.544 & 4.955 & & .000 & & & .000 \\
Years & .273 & .232 & .104 & .240 & 3.604 & .267 & .003 \\
Training & -.135 & .337 & -.032 & .689 & 2.970 & -.202 & .015 & .094 \\
Hours & -.016 & .039 & -.032 & .675 & 2.709 & .133 & .243 & .001 \\
CM/D & .069 & .038 & .124 & .072 & 2.209 & .243 & .000 \\
Loan & .000 & .000 & .125 & .019 & 1.309 & .235 & .712 \\
Age & .032 & .082 & .027 & .693 & 2.116 & -.025 & .586 \\
Education & -.089 & .199 & -.027 & .654 & 1.702 & -.033 & .338 \\
GEM & -.844 & .577 & -.082 & .144 & 1.451 & -.055 & .039 \\
Experience & -.216 & .182 & -.063 & .236 & 1.295 & -.113 & .13 \\
Firm Established & .212 & .227 & .075 & .351 & 2.993 & .103 & .207 \\
NWEA & $-7.113 E-005$ & .000 & -.075 & .170 & 1.375 & -.086 & .137 \\
\hline
\end{tabular}

Note: (Dependent variable) Growth - Venture Growth; (Independent Variables) Years - Number of years; Training - Number of Training Programs Attended, Hours - Number of Hours of Training Programs, CM/D - Number of Centre Meeting or Discussion, and Loan - Total amount of economic loan received; (Control variables) Age, Education, GEM - Number of Gainfully Employed Members, Experience - Prior Entrepreneurial Experience, Firm Established, and NWEA - Net Worth of Enterprise Asset (After)

Source: Author(s) own compilation

The findings presented in Table 10 revealed that years of participation in development initiatives offered in Kelantan had a positive effect $(\mathrm{N}=450$ and $\mathrm{N}=373)$ on post-participation venture growth. However, the effect was statistically significant only after removing the outliers $(\mathrm{N}=373)$. Therefore, this study concludes that the length of participation may lead to venture growth among participants of the development initiatives in Kelantan. However, that which remained inconclusive was the effect of the total number of enterprise development training programs and training hours attended by participating micro-entrepreneurs on microenterprise income. Yet, the effect of the number of centre meetings and/or discussions 
attended by participating micro-entrepreneurs had a positive effect $(\mathrm{N}=450$ and $\mathrm{N}=373)$ and was statistically significant $(\mathrm{N}=373)$ on venture growth. With regards to the total amount of economic loan secured within the development initiatives in Kelantan, the findings showed a significant ( $p$-value less than 0.05 ) positive effect $(\mathrm{N}=450$ and $\mathrm{N}=373)$ on post-participation venture growth. Therefore, this study concludes that the total amount of economic loan received leads to venture growth among the participants from low-income microentrepreneurs in Kelantan. With regards to the effect of control variables, the findings revealed that the effects of age, education, number of gainfully employed members, prior entrepreneurial experience, years of the firm established, and micro-enterprise asset net worth on venture capital were inconclusive and not statistically significant.

\section{Discussion}

The development initiatives programs can be an important tool to lift up the socioeconomic conditions among the low-income micro-entrepreneurs. The findings of this study suggest that participation in development initiatives leads to improvement in micro-enterprise income, assets and venture growth. These improvements are expected to have positive effect on micro-enterprise income, assets and venture growth with the establishment of proper supportive environment. In addition, the development initiatives provided the participants with training, discussion and sharing information. Furthermore, the findings show that the micro-enterprise income, assets and venture growth of participants is better compared to the non-participants. All the positive effects of development initiatives are lead to increases the micro-enterprise income, assets and venture growth of low-income micro-entrepreneurs in Kelantan, Malaysia. As for the impacts of control variables, the outcomes revealed a positive and statistically significant effect of education and micro-enterprise asset net worth on the changes of post-participation micro-enterprise income and the positive and statistically significant effect of average monthly household income on the changes of micro-enterprise assets of participants. These findings were consistent with previous studies that highlight the development initiatives can lead to increases their micro-enterprise income and assets (Terano, Mohamed \& Jusri, 2015).

Furthermore, this study found that the participants need to have basic knowledge of business in order to increase the micro-enterprise income, assets and venture growth. The result indicates that by attend the enterprise development training programs gave opportunity for low-income micro-entrepreneurs to learn about business skills such as create a business plan and carried out risk analysis starting or sustain a business. These training important in evaluating the suitability of the business according to the participants abilities in handling business. The participants in the development initiatives realized that implementation of loan and training in micro-credit create business skills for the low-income micro-entrepreneurs. The result revealed that, training programs provided sufficient knowledge and skill in managing business in term of handling business capital and increases micro-enterprise income, assets and venture growth. Similar result is seen for loans which is participants received loan have increases in micro-enterprise income, assets and venture growth. Indeed, this study parallel with Al-Mamun, Malarvizhi, Hussin \& Tan, (2012) found that micro-credit assistance with providing financial and training can help to improve the socio-economic conditions of poor and hardcore poor.

\section{Conclusion}

The objectives of development initiatives, particularly those commonly achieved through the delivery of access to working capital and enterprise development training 
programs, is to chiefly improve micro-enterprise income generating activities. The findings of this study showed that participation, expressed in terms of a higher number of months, in micro-credit and training programs resulted in the significantly higher amount of postparticipation compared to pre-participation micro-enterprise income and assets. Also, a relatively higher proportion of existing participants in development initiatives was reported to utilize working capital in the services sector, as compared to new participants. This study also showed that the market value of micro-enterprise assets owned by participants in postparticipation was significantly higher than the participants during pre-participation in microcredit and training programs. This indicated the positive effect of development initiatives in the form of access to working capital and enterprise development training programs on microenterprise income, growth, and assets in Kelantan, Malaysia.

In order to accomplish the government's goal in poverty eradication, development organization should design an effective micro-credit program such as the development organization should integrate the micro-credit scheme to the life style of an area by using knowledge of the specific culture and traditions of that area. For the better utilization of the micro-credit program, the provision of basic education and relevant business training should be coupled with the financial support provided by the development organization. At the same time, development organizations in particular AIM, TEKUN and LKIM should further diversify products and services to include insurance policies to protect the low-income microentrepreneurs against possible future economic shocks. Furthermore, AIM, TEKUN, and LKIM should either lengthen the duration of loans or spread the repayment over a longer period of time. This will provide a credit facility that enables participants to utilize credit over a sufficient period of time to build-up income and assets. Therefore, the combination of micro-credit and enterprise development training program is an effective tool to enhance the robustness of income generating activities which could make a difference in micro-enterprise income, growth, and assets towards poverty eradication.

It is important for both the development organization and participants to have regular communication to discuss progress of their business and to make great decision on aspects pertaining any challenges of small business. This enables the participants to discuss the progress of business with the organization or government for the decision and strategies to sustain in business. By doing that, the development organization are able to monitor successful participants in business. Further studies are suggested to expand the sample of the research to the elite group consist of the chairman/CEO of the two institutions. The result might be different because low-income micro-entrepreneurs and elite group have different opinion and understanding of micro-credit and training programs.

\section{Funding}

This research was funded by the Ministry of Higher Education, Malaysia under the grant, entitled "Developing a Comprehensive Rural Entrepreneurship Model for Poverty Eradication (REMODE)" (R/NRGS/A01.00/00047A/006/2014/000149).

\section{References}

Alam, C.M. \& Miyagi, K. (2004). An approachable analysis of micro enterprise in Bangladesh, Working Paper no 8, Department of International Studies, Hagi International University, Japan. (Online) Available at http://www.kitakyu-u.ac.jp/gkj/files/sr004101mk.pdf (10.4.2018).

Al-Mamun, A., Abdul Wahab, S., \& Malarvizhi, C. A. (2010). Impact of Amanah Ikhtiar Malaysia's microcredit schemes on microenterprise assets in Malaysia. International Research Journal of Finance and Economics, 60(2010), 145-154. 
Al-Mamun, A., Abdul Wahab, S., Malarvizhi, C. A., \& Mariapun, S. (2011). Examining the critical factors affecting the repayment of microcredit provided by Amanah Ikhtiar Malaysia. International Business Research, 4(2), 93-102.

Al-Mamun, A., Adaikalam, J. \& Mazumder, M.N.H. (2012). Examining the effect of Amanah Ikhtiar Malaysia's microcredit program on microenterprise asset in Rural Malaysia. Asian Social Science, 8(4), 272-280.

Al-Mamun, A., Malarvizhi, C.A., Hossain, S. \& Tan, S.H. (2012). Examining the effect of microcredit on poverty in Malaysia. Asian Economic Bulletin, 29(1), 15-28.

Al-shami, S. S. A., Razali, R. M., \& Rashid, N. The Effect of Microcredit on Women Empowerment in Welfare and Decisions Making in Malaysia. Social Indicators Research, 121(3), 1-18.

Anderson, L. C., \& Laura, L. (2002). Microcredit, Social Capital and common pool resources. World Development, 30(1), 95-105.

Ariful, C.H., Atanu, D., Ashiqur, R. (2017). The effectiveness of micro-credit programs focusing on household income, expenditure and savings: Evidence from Bangladesh. Journal of Competitiveness, 9(2), 34-44.

Asghar, N. (2012). Micro financing for poverty reduction: An empirical study of rural areas of Tehsil Gujerat-Pakistan. International Journal of Advances in Management and Economics, 1(4), 1419.

Bank Negara Malaysia. (2013). Circular on New Definitions of Small and Medium Enterprise (SME). (Online) Available http://www.bnm.gov.my/index.php?ch=en_announcement\&pg=en_announcement\&ac=110\&la ng=en (2.9.2018).

Barnes, C. (1996). Assets and the impact of Microenterprise Finance Programs. Assessing the Impacts of Microenterprise Services, Washington DC: Management System International. (Online) Available at http://www.microfinancegateway.org/gm/document1.9.28636/28008_file_13.pdf (31.3.2018).

Becker, G. (1993). Human Capital: a theoretical and empirical analysis with special reference o education. ( $2^{\text {nd }}$ Ed.) National Bureau of Economic Research. New York: Columbia University press.

Belas, J., Sipko, J. \& Bilan, Y. (2015). Regional aspects of business environment creation in the SME segment in Slovakia, Mediterranean Journal of Social Sciences, 6(3), 637-645.

Bernat, T., Korpysa, J., Grundey, D., Savrina, B., Bilan, Y. \& Koren, A. (2009). Researching students“ entrepreneurship skills in post-socialist countries: a multi-country survey (part2). Transformations In Business \& Economics, 8(3), 104-130.

Bilan, Y. (2009). Increase diversification throuh strengthened enabling environment for entrepreneurship: A focus on skill endowments and export orientation (example of Hungary and Poland). Economics \& Sociology, 2(2), 33-45.

Claessens, S., \& Tzioumis, K. (2006). Measuring firms' access to finance. At: Access to Finance: Building Inclusive Financial Systems, May 30-31, 2006. Washington, D.C.: USA

Copestake, J., Bhalotra, S., \& Johnson, S. (2001). Assessing the impact of micro working capital: A Zambian case study. Journal of Development Studies, 37(4), 81-100.

DOSM - Department of Statistics Malaysia. (2016). Small and Medium Enterprise Gross Domestic Product (GDP) 2016. (Online) Available at https://www.dosm.gov.my/v1/index.php?r=column/cthemeByCat\&cat=159\&bul_id=YzI2NWE 2U0tXS1VEdnFsWHpqM1Fudz09\&menu_id=TE5CRUZCblh4ZTZMODZIbmk2aWRRQT09 (10.4.2018).

Dunn, E. (2005). Impacts of microcredit on clients in Bosnia and Herzegovina. (Online) Available from: https://www.microfinancegateway.org/sites/default/files/mfg-en-paper-impact-ofmicrocredit-on-clients-in-bosnia-and-herzegovina-2005.pdf (31.03.2018).

Dunn, E., \& Arbuckle, J. G. J. (2001). The Impact of Microcredit: a case Study from Peru. Assessing the Impacts of Microenterprise Services Paper, Washington DC: Management System International. (Online) Available at http://pdf.usaid.gov/pdf_docs/PNACN574.pdf (31.3.2018).

Ellertsson, D. (2012). Access to rural credit and its effect on income equality: Study about rural household in Vietnam. Lund University Centre for East and South-East Asian Studies. (Online) Available at http://lup.lub.lu.se/student-papers/record/3021603/file/3911676.pdf (31.3.18). 
EPU-Economic Planning Unit Malaysia. (2018). Incidence of Poverty by ethnic group, strata and state, Malaysia, 1970-2016. (Online) Available at http://www.epu.gov.my/en/search/node/incidence\%20of\%20poverty (14.4.2018).

Geta, E. \& Hamiso, T. (2017). Access to microcredit and its effect on crop productivity and household income in Hawasa Zuria district of Sidama zone Southern Ethopia. Global Journal of Current Research, 5(3), 128-134.

Hietalahti, J. \& Linden, M. (2006). Socio-economic impacts of microfinance and repayment performance: a case study of small enterprise foundation, South Africa. Progress in Development Studies, 6(3), 201-210.

Hossain, M. (1988). Credit for alleviation of rural poverty: The Grameen Bank in Bangladesh, International Food Policy Research Institute and Bangladesh Institute of Development Studies, Dhaka, Bangladesh. (Online) Available at https://books.google.com/books?hl=en\&lr=\&id=T0zEM_jw2coC\&oi=fnd\&pg=PA7\&dq=Hossa in, + M.+(1988).+Credit+for+the+Alleviation+of+Rural+Poverty.+The+Grameen+bank+in+Ban gladesh.+Research+Report+No.+55,+IFPRI,+Washington,+DC.\&ots=0wk1bJnvh\&sig=B9yj5Z K5DJaYhdkmCBHuMybHmPM (31.3.2018).

Islam, T. (2007). Microcredit and Poverty alleviation. Aldershot, England and Burlington, VT: Ashgate Publishing.

Kasali, T.A., Ahmad, S.A. \& Ean, L.H. (2016). Determinant of microcredit access: Empirical analysis from South-West Nigeria. Journal of Economic Cooperation and Development, 37(4), 125-148.

Kozubikova, L., Belas, J., Bilan, Y. \& Bartos, P. (2015). Personal characteristics of entrepreneurs in the context of perception and management of business risk in the SME segment. Economic and Sociology, 8(1), 41-54.

Latifee, H.I. (2003). Microcredit and poverty reduction. International Conference on Poverty Reduction through Microcredit, Taksim, Istanbul, June 9-10. (Online) Available at http://www.grameentrust.org/wp-content/uploads/bsk-pdf-

manager/3_MICROCREDIT_AND_POVERTY_REDUCTION_JUNE_2003_IN_TURKEYF.P DF (10.4.2018).

Mahmood, S., Hussain, J., \& Z. Matlay, H. (2014). Optimal microfinance loan size and poverty reduction amongst female entrepreneurs in Pakistan. Journal of Small Business and Enterprise Development, 21(2), 231-249.

Md Saad, N. (2011). Selecting high-income generating activities for micro-entrepreneurs: The case study of Amanah Ikhtiar Malaysia. International Journal of Humanities and Social Science, 1(5), 258-264.

Montgomery, H. \& Weiss, J. (2011). Can Commercially-oriented Microfinance Help Meet the Millennium Development Goals? Evidence from Pakistan. World Development, 39(1), 87-109.

Okojie, C.E., Monye-Emina, A., Eghafona, K., Osaghae, G. \& Ehiakhamen, J.O. (2009). Institutional environment and access to microfinance by self-employed women in the rural area of Edo, State in Nigeria, Nigeria Strategy Support Program (NSSP) Background Paper No. Nssp 003, September. (Online) Available http://citeseerx.ist.psu.edu/viewdoc/download?doi=10.1.1.225.5534\&rep=rep1\&type=pdf (1.4.2018).

Omar, M. Z., Noor, C.S.M. \& Dahalan, N. (2012). The economic performance of the Amanah Ikhtiar Malaysia rural microcredit programed: A case study in Kedah. World Journal of Social Sciences, 2(5), 286-302.

Panda, K.D. (2009). Participation in the group based microfinance and its impacts on rural households: A quasi-experimental evidence from the Indian state. Global Journal of Finance and Management, 1(2), 171-183.

Rahman, S., Rafiq, R. B. and Momen, M. A. (2009). Impact of Microcredit Programs on Higher Income Borrowers: Evidence from Bangladesh. International Business \& Economics Research Journal, 8(2), 119-124.

Rosenberg, R. (2010). Does Microfinance Really Help the Poor People? CGAP Focus Note. (Online) Available: (31.3.2018) http://www.cgap.org/publications/does-microcredit-really-help-poor-people. 
Saad, N.M.D. \& Duasa, J. (2011). An economic impacts assessment of a microcredit program in Malaysia: The case of Amanah Ikhtiar Malaysia (AIM). International Journal of Business and Society, 12 (1), 1-14.

Sayvaya, I., \& Kyophilavong, P. (2015). Does microfinance reduce poverty in Lao PDR? International Journal of Development Issues, 14(3), 215-230.

Salma, M. (2004). A Comparative Case Study on Outreach and Impact of Ikhtiar Loan Scheme and Special Program for Hardcore Poor in Seberang Perai Pulau Pinang. Master Thesis, University Science Malaysia. (Online) Available at http://eprints.usm.my/8337/3/indexcodes.txt (1.4.2018).

Samer, S., Majid, I., Rizal, S., Muhamad, M.R., Sarah-Halim, Rashid, N. (2015). The Impacts of microfinance on poverty reduction: Empirical evidence from Malaysian perspective. ProcediaSocial and Behavioral Sciences, 195(2015), 721-728.

Sebstad, J. \& Walsh, M. (1991). Microenterprise credit and its effects in Kenya: An exploratory study. Report prepared for USAID AFR/MDI and S\&T/WID. Washington, DC: Coopers and Lybrand.

Singh, N.T. (2009). Micro finance Practices in India: An Overview, International Review of Business Research Paper, 5(5), 131-146.

SME Annual Report. (2015). Small and Medium Enterprise Annual Report 2015. (Online) Available at http://www.smecorp.gov.my/index.php/en/sme-annual-report-2015-16 (15.4.2018).

Sutoro, A.D. (1990). KUPEDES development impacts survey: Briefing booklet. Planning, Research and Development Department, BRI, Indonesia.

Swain, R.B. \& Varghese, A. (2009). Does Self Help Group Participation Lead to Asset Creation? World Development, 37(10), 1674-1682.

Terano, R., Mohamed, Z. \& Jusri, J.H.H. (2015). Effectiveness of microcredit program and determinants of income among small business entrepreneurs in Malaysia. Journal of Global Entrepreneurship Research, 5(22), 2-14.

Uotila, A. (2005). Livehood Impact of Microfinance access for the poor: The case of vision FINCA Rwanda, Mphil Thesis, The University of Guelph, Canada.

World Bank. (2018). Poverty Overview. Retrieved March 23, 2019 from https://www.worldbank.org/en/topic/poverty/overview 